\title{
Passwords
}

Volume 13 | Issue 1

Article 15

$12-20-2012$

\section{The Second Wailing Wall}

Jordan Wilson-Dalzell

jowilson@students.pitzer.edu

Follow this and additional works at: http://scholarship.claremont.edu/passwords

Cart of the Art and Design Commons, Creative Writing Commons, and the Photography $\underline{\text { Commons }}$

\section{Recommended Citation}

Wilson-Dalzell, Jordan (2012) "The Second Wailing Wall," Passwords: Vol. 13: Iss. 1, Article 15. DOI: 10.5642/passwrd.20121301.15 Available at: http://scholarship.claremont.edu/passwords/vol13/iss1/15

This Poetry is brought to you for free and open access by the Journals at Claremont at Scholarship @ Claremont. It has been accepted for inclusion in

Passwords by an authorized administrator of Scholarship @ Claremont. For more information, please contact scholarship@cuc.claremont.edu. 


\section{The Second Wailing Wall}

i.

Hot,

too hot.

My skin melts,

in liquid strokes

it slides from my frame.

Shrapnel swiftly shreds me,

digging my heart from my chest.

Wind blows bloody dust around us, splattering us with each others' parts.

Bodies litter the sidewalks; the bomb blew out both yellow stars and yellow crescents, short circuiting victims on both sides of the war. Buildings sway and weep while the streets wail out their grief. Tiny eyes locked with mine, someone's little girl reddened the sky

with someone else's hate. 
ii.

\section{Terrorist. Terrorist.}

A Jerusalem bus is crowded with yammukahs and fear.

Sallow old men with wrinkles and numbers on their skin stamp their feet anxiously; they shake their heads from side to side, biting through cracked lips. Children sprawl in tired arms; their mothers cup still-growing elbows and knees, lips barely grazing sticky foreheads. Eyes wary and waiting, they are all ready to stampede to the door. Bones creak like stairways in a collapsing building: a prediction of demise.

Hazel eyes and a white hijab climb onto the lumbering vehicle. Thirty faces flash with hostility and alarm as she looks for a place to sit. A baby whimpers into her chest, black tufts of hair peeking out from her embrace. The engine backfires as the bus lurches forward. Everyone else hears a gunshot, and cowers without a second thought. The adults point gnarled fingers at the green-eyed girl. As she tries to soothe him an old woman with ashen skin begins to speak.

It began like a biccup, a whisper, and a rumor. At first it is hidden by hushed coughs but soon it has its own echo. 'Terrorist, she's a terrorist.' The windows seem to take up the cry, rattling with the force of these wails. Wheels screech like nails on a blackboard and babies join the clamor, creating a bysterical harmony.

\section{Terrorist. Terrorists. Terrorist. Terrorists.}

They're burning words, ones that char the tongue. She fuses to the floor, cheeks red with shame. The sheer veil lets her curls escape, as if her hair wants to run from the whispers creeping inside. The door opens and she steps out at her stop. 
iii.

they are building a wall, one of mortar and rock across the west bank. they claim to use shovels, but i've seen arms, cradling guns and hate;

a baby they nursed with bloody hands, the child they spoon-fed fear.

they say it will protect us, from the children who explode in shrapnel and anger, from those who would destroy the Jews

i take her by the hand, her thumb is painted black, just like mine, cheap nail polish lining thrift store shelves, and we sit.

we are the same.

רבד ותוא ונחנא

she repeats.

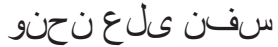

